\title{
LATE-STAGE INTRUSIVE ACTIVITY AT OLYMPUS MONS, MARS: SUMMIT INFLATION AND GIANT DIKE FORMATION
}

\author{
Peter J. Mouginis-Mark ${ }^{1 *}$ and Lionel Wilson ${ }^{2}$
}

\author{
${ }^{1}$ Hawaii Institute of Geophysics and Planetology \\ University of Hawaii \\ Honolulu, Hawaii 96822 \\ USA \\ ${ }^{2}$ Lancaster Environment Centre \\ Lancaster University \\ Lancaster LA1 4YQ \\ UK
}

\section{Icarus}

In press, September 2018

\section{Keywords: \\ Mars \\ Olympus Mons \\ Ascraeus Mons \\ Volcanic dikes}




\section{Abstract}

2 By mapping the distribution of 351 lava flows at the summit area of Olympus Mons

3 volcano on Mars, and correlating these flows with the current topography from the Mars

4 Orbiter Laser Altimeter (MOLA), we have identified numerous flows which appear to have

5 moved uphill. This disparity is most clearly seen to the south of the caldera rim, where the

6 elevation increases by $>200 \mathrm{~m}$ along the apparent path of the flow. Additional present day

7 topographic anomalies have been identified, including the tilting down towards the north

8 of the floors of Apollo and Hermes Paterae within the caldera, and an elevation difference

9 of $>400 \mathrm{~m}$ between the northern and southern portions of the floor of Zeus Patera. We

10 conclude that inflation of the southern flank after the eruption of the youngest lava flows

11 is the most plausible explanation, which implies that intrusive activity at Olympus Mons

12 continued towards the present beyond the age of the youngest paterae $\sim 200-300 \mathrm{Myr}$

13 (Neukum et al., 2004; Robbins et al., 2011). We propose that intrusion of lateral dikes to

14 radial distances $>2,000 \mathrm{~km}$ is linked to the formation of the individual paterae at Olympus

15 Mons. Two specific dikes to the SE of the volcano are inferred to have volumes of $\sim 4,400$

$16 \mathrm{~km}^{3}$ and $\sim 6,100 \mathrm{~km}^{3}$, greater than the volumes of individual calderas and implying

17 triggering of both caldera collapse and lateral dike injection by the arrival of large inputs

18 of magma from the mantle. A comparable disparity between lava flow direction and

19 current topography, together with a tilted part of the caldera floor, has been identified at

20 Ascraeus Mons. 


\section{Introduction}

23 The Martian volcano Olympus Mons $\left(18.65^{\circ} \mathrm{N}, 226.2^{\circ} \mathrm{E}\right)$ possesses a summit caldera

$24 \sim 60 \times 80 \mathrm{~km}$ in diameter comprising six overlapping collapse pits ("paterae"), and the

25 geology of the volcano has been compared to that of volcanoes in Hawai'i (Carr, 1981;

26 Hodges and Moore, 1994) and Nicaragua (Mouginis-Mark et al., 2007). Numerous lava

27 flows originate from the caldera rim and extend to the lower flanks, and the vents for these

28 flows are missing, presumed destroyed within the calderas following late-stage summit

29 collapse (Mouginis-Mark, 1981; Mouginis-Mark and Robinson, 1992). Our comparison

30 of lava flow directions with topographic data collected from the Mars Orbiter Laser

31 Altimeter (MOLA) (Smith et al., 2001) reveals that flows on the southern rim of Olympus

32 Mons caldera apparently travelled uphill. In addition, the highest point on the volcano is

33 off-set from the center-of-figure of the shield. The high point on the volcano is $>200 \mathrm{~m}$

34 higher than any point on the caldera rim crest, and $>1,600 \mathrm{~m}$ higher than the northern

35 caldera rim. While disparities between lava flow directions beyond the basal escarpment

36 of Olympus Mons have previously been reported (Mouginis-Mark et al., 1982; Isherwood

37 et al., 2013; Chadwick et al., 2015), this is the first time that such topographic and flow

38 direction differences have been recognized close to the summit.

39 We contend that the emplacement of the lava flows predates the latest period of

40 summit inflation at the volcano, indicating that the parent magma chamber remained

41 molten, and continued to receive new magma from depth, after the latest episodes of

42 caldera collapse. Here, we propose that caldera collapse may have been linked to the

43 emplacement of lateral dikes extending to significant distances (in some instances $>2,000$

$44 \mathrm{~km}$ ) from Olympus Mons, and that the last phase of summit inflation was insufficient to 
45 initiate further dike intrusions. This suggests a minimum volume-limited threshold for dike

46 emplacement and associated caldera collapse. Two candidate dikes are identified to the

47 south and SE of Olympus Mons; these have calculated volumes comparable to that of the

48 paterae but greater than the post-collapse inflation of the summit. These observations

49 indicate that magmatism within the Tharsis region of Mars took place more recently than

50 indicated by crater counts of the summit areas (Neukum et al., 2004; Robbins et al., 2011),

51 perhaps as recently as $<200$ Myr. Supporting this idea, Hauber et al. (2011) have identified

52 individual lava flows to the east of Olympus Mons and Pavonis Mons which may also be

53 younger than 100 Myr. Cumulative size/frequency crater curves derived by Warner (2009;

54 her Fig. 4) and Richardson et al. (2017) also suggest that some small flows on Arsia Mons

55 may be comparably young. Our analysis of the summit areas of other Martian volcanoes

56 reveals that comparable post-collapse inflation has taken place at Ascraeus Mons, but that

57 the summit areas of other Tharsis volcanoes do not have this attribute.

\section{Observations}

60 We have mapped the distribution of lava flows at the summit of Olympus Mons,

61 using images from the Context Camera (CTX) (Malin et al., 2007) and the High Resolution

62 Imaging Science Experiment (HiRISE) (McEwen et al., 2007) instruments, which provide

63 visible images with a spatial resolution of $\sim 6 \mathrm{~m} /$ pixel and $\sim 0.25 \mathrm{~m} /$ pixel, respectively. We

64 have mapped 351 individual lava flows and lava channels at the summit of Olympus Mons

65 (Fig. 1), of which 28 are truncated by the caldera rim. All of the mapped flows are $>10 \mathrm{~km}$

66 in length, and are recognized either by the lobate edges of individual flow lobes or by a

67 continuous central lava channel. No clear examples of vents can be identified for any of 
68 these flows, which leads us to support the idea that the flows originated within a summit

69 area since destroyed by caldera collapse (Mouginis-Mark, 1981, 2017; Mouginis-Mark and

70 Robinson, 1992).

71 Comparing topographic data from MOLA with the mapped lava flow locations (Fig.

72 1) reveals that there is a marked difference between the direction of flow and the maximum

73 topographic gradient on the southern upper flank. Flows originating from the southern rim

74 of Apollo Patera extend uphill by $>200 \mathrm{~m}$, crossing the contours at $\sim 90^{\circ}$ (Figs. 2 and 3).

75 On the eastern rim, the flows parallel the contours. Only on the northern rims of Zeus and

76 Athena Paterae do the flows cross the contours perpendicularly and travel downhill in the

77 expected direction.

78 The floors of the Olympus Mons paterae are interpreted to be solidified lava lakes, or

79 extensive individual lava flows which buried the talus produced during caldera collapse

80 under a relatively thin veneer of fresh lava (Mouginis-Mark, 2017). We contend that soon

81 after formation each patera floor would have been an equipotential surface, i.e., a locally

82 horizontal surface. However, topographic profiles across the floors of Hermes and Apollo

83 Paterae reveal that they are tilted towards the area of maximum elevation on the volcano

84 by $\sim 1^{\circ}$ (Fig. 4). Apollo Patera is $\sim 100 \mathrm{~m}$ higher on the SW floor compared to the NE floor,

85 and Hermes Patera is $\sim 320 \mathrm{~m}$ higher on the SW floor compared to the NE floor. Multiple

86 wrinkle ridges on the floor of Hermes Patera appear to be consistent with post-formation

87 uplift of the floor (most likely during several discrete episodes), while other ridges and

88 graben within Zeus Patera may in part be due to "sagging" of the central portion of the

89 floor (Zuber and Mouginis-Mark, 1992). 
Additional evidence exists for changes in the topography of the caldera floor post-

91 formation. The floor of Zeus Patera, which is the first and largest of the collapse features

92 within the caldera, most likely formed a horizontal surface because it appears to have

93 formed in a single event. However, present topography (Fig. 5) shows that the southern

94 portion of the floor lies at an elevation $\sim 400 \mathrm{~m}$ higher than the northern floor. Most of the

95 circumferential graben on the floor (Zuber and Mouginis-Mark, 1992) lie below an

96 elevation of $18.90 \mathrm{~km}$ on the northern portion and above this elevation on the southern

97 floor. This suggests that either the southern floor was raised or, less likely, that the northern

98 floor subsided by this amount. The simplest interpretation consistent with the disparity

99 between lava flow directions and present topography is that the southern floor has been

100 raised by $\sim 400 \mathrm{~m}$, with the foot of the southern wall of Zeus Patera at $\sim 19.30 \mathrm{~km}$ elevation

101 (Fig. 5). It is not possible to determine the relative timing of some of these tilting events.

102 At least part of the $\sim 400 \mathrm{~m}$ uplift of Zeus Patera could have taken place prior to the

103 formation of Hermes or Apollo Paterae, as there is a pronounced sequence of events for

104 the evolution of the caldera, with Zeus Patera the oldest (Mouginis-Mark, 2017).

105 In contrast, Athena Patera displays no obvious tilting of its floor (Fig. 6). The

106 elevation of the floor varies from a high point of $\sim 18.04 \mathrm{~km}$ and a low point of $\sim 17.71 \mathrm{~km}$.

107 In general, the floor is higher around the perimeter, with a low dome ( 100 $\mathrm{m}$ high) on the

108 NE floor. The lack of clear evidence of tilting of the floor may be because Athena Patera

109 lies further from the center of uplift, or it may indicate that this collapse pit is the youngest

110 collapse event and formed after uplift had ceased. Stratigraphically, Athena Patera could

111 be as old as any patera except Zeus Patera. Morphologic data are not available to resolve

112 which explanation is more likely, but crater counts (Neukum et al., 2004; Robbins et al., 
113 2011) suggest that Athena Patera is one of the older collapse features. However, Mouginis-

114 Mark (2017) showed that previous crater counts for the caldera are contaminated by

115 secondary craters from the impact crater Pangboche, so that a direct crater-age comparison

116 between Apollo and Athena Paterae is not possible.

117 A further test for the spatial extent of the inferred uplift comes from an inspection of

118 the floor of the $10.4 \mathrm{~km}$ diameter Pangboche crater (Fig. 7), which lies $<20 \mathrm{~km}$ from the

119 highest point on the volcano. Ejecta from Pangboche crater extends across the floors of

120 Apollo and Dionysus Paterae, so that the crater formed at some time after the latest episodes

121 of caldera collapse (Mouginis-Mark, 2017). As documented by Mouginis-Mark (2015),

122 there is a well-preserved deposit of impact melt on the floor of Pangboche crater. This

123 melt most likely cooled as a single unit, and formed a horizontal surface. Inspection of a

124 HiRISE-derived digital elevation model (Fig. 7) reveals that the eastern portion of this melt

125 pond is horizontal, with $\sim 5 \mathrm{~m}$ difference in elevation between the northern and southern

126 portions of the floor. Thus, since the formation of Pangboche crater, there has been no

127 further inflation of the summit.

\section{Patera Formation}

130 The lack of large-volume lava flows which have vents on the flanks of Olympus

131 Mons (Mouginis-Mark, 2017), which might have caused incremental caldera collapse due

132 to multiple flank eruptions, requires an alternative explanation for the initiation of caldera

133 collapse. For example, Mouginis-Mark (2017) found no evidence for previously proposed

134 flank vents on Olympus Mons (Peters and Christensen, 2017), concluding that changes in

135 flank flow morphology are due to subtle differences in slope. The formation of nested 
136 calderas implies multiple collapse events each triggered by the partial evacuation of the

137 subsurface magma chamber(s) with a change in volume per event ranging from $\sim 412$ to

$1383,675 \mathrm{~km}^{3}$, with a total volume of $6,242 \mathrm{~km}^{3}$ (Table 1). Subsidence of an evolving magma

139 chamber into a lower zone of hot crustal rocks was proposed (Walker, 1988) as a viable

140 mechanism leading to surface collapse at Hawaiian volcanoes, which may serve as a good

141 terrestrial analog. At other volcanoes on Earth it is possible that unrecognized distal flank

142 eruptions and intrusions during the caldera collapse event might explain magma loss from

143 the summit region (Simkin and Howard, 1970; Sigurdsson and Spark, 1978).

144 Our model for the formation of the individual paterae within the Olympus Mons

145 caldera is that each subsidence event was initiated by the intrusion of a large lateral dike

146 extending to a great distance radial to the volcano. For a range of plausible model

147 parameters (Zuber and Mouginis-Mark, 1992), the maximum depth to the top of the active

148 magma chamber of Olympus Mons must have been $<16 \mathrm{~km}$. A simple magma chamber

149 model consists of magma with density $\rho_{m}$ filling a chamber with vertical height $H$ centered

150 at a neutral buoyancy level. This level is located at depth $D$ below the surface between

151 upper crustal rocks of density $\rho_{u}$ and lower crustal rocks of density $\rho_{l}$, such that $\rho_{l}>\rho_{m}>$

$152 \rho_{u}$. Neutral buoyancy requires that $\left(\rho_{l}-\rho_{m}\right)=\left(\rho_{m}-\rho_{u}\right)$. We adopt inferred magma density

153 values (Rubin and Pollard, 1987) for Kilauea volcano, i.e., $\rho l, \rho_{m}$ and $\rho_{u}$ equal to 2900 ,

1542600 and $2300 \mathrm{~kg} \mathrm{~m}^{-3}$, respectively, for which $\left(\rho_{l}-\rho_{m}\right)=\left(\rho_{m}-\rho_{u}\right)=\Delta \rho=300 \mathrm{~kg} \mathrm{~m}^{-3}$. With

155 this simple configuration, the excess magma pressure, $\Delta P$, inside the chamber acting to

156 fracture the chamber wall is a maximum at the chamber center-line at depth $D$ and has the

157 value $(0.5 \mathrm{~g} \mathrm{H} \Delta \rho)$ where $g$ is the acceleration due to gravity, $3.711 \mathrm{~m} \mathrm{~s}^{-2}$. If magma

158 chambers commonly grow into a roughly spherical shape, then the 20 to $50 \mathrm{~km}$ diameters 
159 of the Olympus Mons summit paterae suggest that $H$ could be at least $20 \mathrm{~km}$, in which case

$160 \triangle P$ would be at least $11 \mathrm{MPa}$. This value is of the same order as the expected tensile

161 strengths of rocks (Roy et al., 1981) suggesting that the proposed model is plausible. With

162 the top of the chamber at a depth of $16 \mathrm{~km}$ for Olympus Mons (Zuber and Mouginis-Mark,

163 1992) and a chamber height of $20 \mathrm{~km}$, dikes leaving the chamber would have propagated

164 laterally from its mid-line at a depth of at least $26 \mathrm{~km}$ (i.e., $16+0.5 \times 20 \mathrm{~km}$ ) below the

165 volcano summit, i.e., at least $\sim 4 \mathrm{~km}$ below the mean surface level surrounding the volcano.

166 We have searched for large graben radial to Olympus Mons which would be the

167 surface traces of large dikes. We speculate that each collapse event which formed a patera

168 within the caldera was connected with a lateral dike intrusion, but of course cannot

169 correlate a specific dike with a specific collapse event. Two clear candidate dikes exist to

170 the SE, namely Aganippe Fossa $\left(7^{\circ} 00^{\prime} \mathrm{S}, 233^{\circ} 40^{\prime} \mathrm{E}\right)$, extending to $\sim 1,710 \mathrm{~km}$ from the

171 center of the caldera, and a graben in Phoenicis Lacus $\left(13^{\circ} 00^{\prime} \mathrm{S}, 249^{\circ} 40^{\prime} \mathrm{E}\right)$ extending to

$172 \sim 2,530 \mathrm{~km}$ from the caldera (Fig. 8). Aganippe Fossa is $\sim 425 \mathrm{~km}$ long and lacks discrete

173 pits, but the bounding graben walls are $\sim 3$ to $7 \mathrm{~km}$ apart. Other, unidentified, dikes are

174 postulated to have been linked to the formation of the other paterae. Numerous fractures

175 within Ulysses Fossae $\left(12^{\circ} \mathrm{N}, 237^{\circ} \mathrm{E}\right)$ are radial to Olympus Mons, and thus might be the

176 surface manifestations of dikes related to caldera collapse episodes. The surface expression

177 of the Phoenicis Lacus graben extends for $\sim 185 \mathrm{~km}$ and comprises a series of connected

178 rimless pits $\sim 4 \mathrm{~km}$ in diameter, with bounding graben walls (Fig. 9). The width and depth

179 of each graben was measured (using CTX images and MOLA topography, respectively),

180 at a series of locations as shown in Fig. 8 and these geometric data are given in Table 2.

181 The general trend with increasing distance from Olympus Mons is for the broad depression 
182 of the Phoenicus graben to narrow and then break into a series of coalescing pits, and final

183 individual pits. This is consistent with observations of the collapse features associated with

184 the dike system approaching the surface along the East Rift Zone of Kilauea volcano,

185 Hawai'i (Okubo and Martel, 1998).

186 The values in parentheses in Table 2 are locations where the grabens are anomalously

187 wide, possibly due to magma withdrawal and surface subsidence or localized minor

188 explosive activity. Ignoring these locations, as measured at the surface, the average depth

189 and width of the Aganippe graben are $345 \mathrm{~m}$ and $7.5 \mathrm{~km}$, respectively. The corresponding

190 values for the Phoenicis graben are $320 \mathrm{~m}$ and $4.2 \mathrm{~km}$. Based on measurements of two

191 dike-induced graben in Iceland (Rubin, 1992), the ratio (graben width) / (depth to dike top)

192 (Wilson and Head, 2002) is on average 3.5 and the ratio (dike width) / (vertical subsidence

193 of graben floor) is 1.25 . Using these ratios, we find that the Aganippe dike was $\sim 430 \mathrm{~m}$

194 wide with its top at a depth of $2.1 \mathrm{~km}$ below the surface and that the Phoenicis dike was

$195400 \mathrm{~m}$ wide with its top $1.2 \mathrm{~km}$ deep.

196 We noted above that any radial dike leaving a magma chamber inside Olympus Mons

197 probably had its center at a depth of at least $4 \mathrm{~km}$ below the general planetary surface level.

198 At the locations of the graben, our measurements imply that the dike tops were at a depth

199 of $1 \mathrm{~km}$ to $2 \mathrm{~km}$. This suggests that the half-heights of the dikes were at least $\sim 3 \mathrm{~km}$.

200 Multiplying total dike heights of $6 \mathrm{~km}$ by the above estimated widths and the extents of the

201 dikes from Olympus Mons we find minimum magma volumes in the dikes of 4,400 $\mathrm{km}^{3}$

202 for Aganippe and $6,070 \mathrm{~km}^{3}$ for Phoenicis, a total of at least $\sim 10,500 \mathrm{~km}^{3}$.

203 The waning phase of activity at Olympus Mons was evidently characterized by the

204 cessation of the eruption of lava flows from vents at the summit followed by caldera 
205 collapse events linked to the propagation of large lateral dikes able to extend a few

206 thousand kilometers from the volcano. Because the volumes of the lateral dikes are greater

207 than that of even the largest patera, it seems probable that magma must have been

208 "buffered" within the edifice (Parfitt and Head, 1993; Parfitt et al., 1993). It is also likely

209 that any magma chamber was only partially emptied. This dike intrusion could occur at

210 the end of the life of a magma chamber when the arrival of an unusually large dike rising

211 from the mantle inflated the magma chamber to the point where multiple ruptures occur.

212 Not only is a lateral dike initiated, but also the stresses on the overlying rocks cause caldera

213 collapse to begin. The volume of magma intruded into the lateral dike consists of

214 contributions from both the caldera subsidence and the new mantle magma. Multiple

215 episodes of this kind of activity occurred at Olympus Mons, with the latest collapse

216 occurring $200-300 \mathrm{Myr}$ ago (Neukum et al., 2004; Robbins et al., 2011). There are

217 insufficient topographic and morphologic data to resolve if inflation preceded each caldera

218 collapse event, or if the difference in lava flow direction and present topography is due to

219 the single most recent event or to multiple smaller inflation events. Thus, some of the 400

$220 \mathrm{~m}$ uplift of the southern floor of Zeus Patera may be a relic of an earlier inflation event

221 which ultimately produced a younger patera (such as Apollo Patera).

222 It is not easy to compare the volume of each dike with the volume of the inflated area

223 at the summit of Olympus Mons, primarily because the horizontal extent of this uplift is

224 not clear. If all of the uplift resulted from a single event (rather than multiple episodes of

225 inflation followed by caldera collapse), then the horizontal extent of uplift could reasonably

226 be defined by the $20.0 \mathrm{~km}$ contour on the volcano (Fig. 1). This contour defines an

227 approximate width of inflation as $100 \mathrm{~km}$. Taking the maximum elevation of the southern 
228 rim (i.e., $\sim 21.20 \mathrm{~km}$ ) as the center of uplift, and approximating the shape of the uplift as a

229 cone, this would imply a volume of $\sim 3,150 \mathrm{~km}^{3}$. This volume is $\sim 50 \%$ to $70 \%$ the inferred

230 volume of the lateral dikes that we have identified, and so would be consistent with the

231 inability of the last inflation event to drive a new episode of dike intrusion.

232 The following sequence of events at Olympus Mons can be inferred from the

233 distribution of flows and the topography of the paterae floors: 1. The paleo-summit began

234 as a topographic high that lacked a caldera complex. 2. Lava flows erupted from this

235 summit area, and extended down the flanks of the volcano. 3. Successive collapses of

236 Zeus, Hera, Hermes and Dionysus Paterae took place, most likely linked with lateral dike

237 intrusions which, by virtue of their inferred volumes, extended more than $1,000 \mathrm{~km}$ from

238 the summit. The lava flows at the caldera rim were truncated and the vents were destroyed.

239 4. Inflation south of the summit began, tilting the floor of Zeus and Hermes Paterae. 5.

240 Collapse of Apollo Patera took place due to a later phase of distal dike intrusion. 6.

241 Inflation south of the caldera continued, tilting the floor of Apollo Patera, and continuing

242 to tilt the floor of Hermes Patera. 7. Pangboche crater formed after the summit inflation

243 had ceased.

244

245 Topography of Other Martian Volcanoes

246 Results comparable to Olympus Mons have been found for the summit of Ascraeus

247 Mons (Fig. 10), where our mapping has identified 126 individual lava flows. Here the

248 mismatch between flow direction and present day topography is greatest on the northern

249 rim of the caldera, where truncated flows are evident on the rim (Mouginis-Mark and

250 Rowland, 2001; Mouginis-Mark and Christensen, 2005). Examples of lava flows which 
251 now go uphill, or parallel the present contours, can be identified (Fig. 11). The total height

252 difference across this summit area north of the caldera rim is $\sim 100 \mathrm{~m}$. At Ascraeus Mons,

253 there appears to have been tilting of at least one of the paterae (not named) on the northern

254 side of the caldera. The patera is proximal to the highest point on the volcano, and is $\sim 300$

$255 \mathrm{~m}$ higher on its northern floor compared with the southern floor (Fig. 12). This appears to

256 have been true tilting of the floor, rather than subsidence of the center of the patera, as the

257 slope extends across the entire floor and the tilting is radial to the high-point. Inspection

258 of the largest patera at the middle of the Ascraeus Mons caldera, which is the youngest of

259 the collapse events (Mouginis-Mark, 1981), reveals no comparable tilting. We have

260 performed a search for graben radial to Ascraeus Mons to explain the origin of the caldera.

261 Numerous fractures which are sub-radial to Ascraeus Mons can be found within Tractus

262 Catena $\left(25^{\circ} 00^{\prime} \mathrm{N}, 257^{\circ} 00^{\prime} \mathrm{E}\right)$ to the north of the volcano, and within Uranius Fossae

$263\left(23^{\circ} 10^{\prime} \mathrm{N}, 268^{\circ} 30^{\prime} \mathrm{E}\right)$ to the NE. However, the complex history of tectonic stresses in these

264 areas makes it difficult to associate these features unambiguously with Ascraeus Mons.

265 Although we have found this topographic disparity at two of the Tharsis volcanoes, a

266 review of lava flow distributions and MOLA topography reveals that there is no

267 comparable evidence for late-stage summit inflation at either Pavonis or Arsia Montes. A

268 possible explanation could be that these two volcanoes have lower maximum elevations,

$269 \sim 17.6 \mathrm{~km}$ at the western and southern rims of Arsia Mons and $\sim 14.0 \mathrm{~km}$ on the southern

270 rim of Pavonis Mons, compared with $18.2 \mathrm{~km}$ for Ascraeus Mons and $\sim 21.2 \mathrm{~km}$ for

271 Olympus Mons. Other attributes of each volcano may also come into play. For example,

272 regional extensional tectonics more easily facilitating the intrusion of large dikes, as at

273 Ceraunius Fossae south of Alba Mons, may have promoted the formation of nested calderas 
274 on Alba Mons (Mouginis-Mark et al., 1988; Schneeberger and Pieri, 1991; Ivanov and

275 Head, 2006) at lower elevations. We note that the highest elevation on Alba Mons ( 6.80

$276 \mathrm{~km}$ ) lies to the west of the caldera rim, with a dome $\sim 300 \mathrm{~m}$ high located in the western

277 rim of the volcano (McGovern et al., 2001), and that the mapped distribution of lava flows

278 (Crown et al., 2017) is suggestive of late-stage inflation. Late-stage inflation of the western

279 flank of Alba Mons may also explain the mismatch between the predicted dike orientations

280 from doming centered on the calderas (Cailleau et al., 2005).

281 Elysium Mons (maximum rim elevation $\sim 14.0 \mathrm{~km}$ on the northern and southern rims)

282 has a caldera floor tilted down towards the east, but no lava flows can be identified at the

283 summit. Tilting of an old portion of the caldera floor at Apollinaris Mons (rim elevation

$284 \sim 3.5 \mathrm{~km}$ ) has previously been identified (Robinson et al., 1993), but again the lack of 285 recognizable lava flows precludes a comparison of flow directions and topography. Albor

286 Mons (rim elevation $\sim 3.9 \mathrm{~km}$ on the southern rim) displays caldera floor topography 287 consistent with the sagging of the central portion, with the perimeter $\sim 600 \mathrm{~m}$ higher than

288 the center of the caldera. Similarly, the central portion of the floor of Uranius Mons (rim

289 elevation $\sim 2.3 \mathrm{~km}$ ) is $\sim 500 \mathrm{~m}$ lower than the perimeter. We leave to a future investigation

290 an analysis of how a particular volcano may experience summit inflation, the formation of

291 large-volume radial dikes, and how these attributes may relate to the neutral density level

292 of the magma chamber (Wilson and Head, 2002; Scott et al., 2002).

\section{Conclusions}

295 Our observations of the summits of Olympus and Ascraeus Montes imply that 296 igneous activity on Mars continued closer towards the present day than previously inferred 
297 from crater counting of the geological units on the caldera floors (Neukum et al., 2004;

298 Robbins et al., 2011). If the Phoenicus graben and Aganippe Fossa are indeed the surface

299 manifestation of dikes from Olympus Mons, then it is possible that the influence of an

300 individual volcano may extend to thousands of kilometers from the construct. Such a

301 conclusion is consistent with the idea that a giant dike from Arsia Mons initiated the

302 outflow of water which formed Mangala Vallis (Wilson and Head, 2004), and that large

303 dikes from Elysium Mons could have been responsible for the formation of Hrad Vallis

304 (Wilson and Mouginis-Mark, 2003).

305 It is evident that the magma chambers within Olympus and Ascraeus Montes were

306 fed with new magma from the mantle after the floors of the summit calderas were created,

307 causing each chamber to inflate. The duration of these inflation events cannot be resolved,

308 but potentially collecting age dates (through detailed crater counting of high-resolution

309 images) for the surface expressions of the radial dikes might provide such information.

310 Such analyses would be important for estimating the timing of this last phase of igneous

311 activity, but await a future investigation.

312

313 Acknowledgements

314 This work results from detailed geologic mapping of Olympus Mons under NASA grant

315 NNG05GH51G. LW acknowledges support from the Leverhulme Trust via an Emeritus

316 Fellowship. We thank Harold Garbeil for the production of the digital elevation model

317 presented in Figure 7, and two anonymous reviewers for their constructive comments on 318 earlier versions of this manuscript. 


\section{References}

320 Cailleau, B., Walter, T. R., Janle, P., Hauber, E., 2005. Unveiling the origin of radial 321 grabens on Alba Patera volcano by finite element modelling. Icarus 176, $44-56$.

322 Carr, M. H., 1981. The surface of Mars. Yale University Press, pp. $87-110$.

323 Chadwick, J., McGovern, P., Simpson, M., Reeves, A., 2015. Late Amazonian subsidence 324 and magmatism of Olympus Mons. J. Geophys. Res. 120, 325 doi:10.1002/2015JE004875.

326 Crown, D. A., Berman, D. C., Platz, T., Svheidt, S. P., Hauber, E., Weitz, C. M., 2017.

327 Geologic mapping of the summit and western flank of Alba Mons, Mars. $3^{\text {rd }}$ $328 \quad$ Planetary data Workshop 2017, LPI Contr. 1986.

329 Hauber, E., Broz, P., Jagert, F., P. Jodlowski, Platz, T., 2011. Very recent and wide-spread 330 basaltic volcanism on Mars. Geophys. Res. Lttrs. 38, L10201, doi: $331 \quad 10.1029 / 2011$ GL0473110.

332 Hodges, C. A., Moore, H. J., 1994. Atlas of volcanic landforms on Mars. U.S. Geological 333 Survey Prof. Paper 1534.

334 Isherwood, R. J., Jozwiak, L. M., Jansen, J. C., Andrews-Hanna, J. C., 2013. The volcanic 335 history of Olympus Mons from paleo-topography and flexural modeling. Earth $336 \quad$ Planet. Sci. Lttrs. 363, $88-96$.

337 Ivanov, M. A., Head, J. W., 2006. Alba Patera, Mars: Topography, structure, and evolution 338 of a unique late Hesperian-early Amazonian shield volcano. J. Geophys. Res. 111 339 (E9), doi: 10.1029/2005JE002469.

340 Malin, M. C. and 13 others, 2007. Context Camera investigation on board the Mars

341 Reconnaissance Orbiter. J. Geophys. Res. 112 (E5), doi: 10.1029/2006JE002808. 
342 McEwen, A. S. and 14 others, 2007. Mars Reconnaissance Orbiter's High Resolution

343 Imaging Science Experiment (HiRISE). J. Geophys. Res. 112 (E5), doi:

$344 \quad 10.1029 / 2005 J E 002605$.

345 McGovern, P. J., Solomon, S. C., Head, J. W., Smith, D. E., Zuber, M. T., Neumann, G.

346 A., 2001. Extension and uplift at Alba Patera, Mars: Insights from MOLA

347 observations and loading models. J. Geophys. Res. 106 (no. E10), 23,769-23,809.

348 Mouginis-Mark, P. J., 1981. Late-stage summit activity of martian shield volcanoes. Proc.

349 Lunar Planet. Conf. 12 $2^{\text {th }}$, p. 1431-1447.

350 Mouginis-Mark, P. J., 2015. Cratering on Mars with almost no atmosphere or volatiles:

351 Pangboche crater. Meteoritics Planet. Sci. 50 (1), $51-62$.

352 Mouginis-Mark, P. J., 2017. Olympus Mons volcano, Mars: A photogeologic view and 353 new insights. Chemie der Erde, https://doi.org/10.1016/j.chemer.2017.11.006.

354 Mouginis-Mark, P. J., Christensen, P. R., 2005. New observations of volcanic features on

355 Mars from the THEMIS instrument. J. Geophys. Res. 110 (E08), 356 doi:10/1029/2005JE002421.

357 Mouginis-Mark, P. J., Robinson, M., 1992. Evolution of the Olympus Mons caldera, Mars. $358 \quad$ Bull. Volcanol. 54, $347-360$.

359 Mouginis-Mark, P. J., Rowland, S. K., 2001. The geomorphology of planetary $360 \quad$ calderas. Geomorphology, 37, 201-223.

361 Mouginis-Mark, P. J., Harris, A. J. L., Rowland, S. K., 2007. Terrestrial analogs to the 362 calderas of the Tharsis volcanoes of Mars: in: The Geology of Mars: Evidence from 363 Earth-based Analogs, ed. M. Chapman, Cambridge University Press, p. 71 - 94. 
364 Mouginis-Mark, P. J., Wilson, L., Zimbelman J. R., 1988. Polygenic eruptions on Alba 365 Patera, Mars. Bull. Volcanol. 50 (6), $361-379$.

366 Mouginis-Mark, P. J., Zisk, S. H., Downs, G. S., 1982. Ancient and modern slopes in the 367 Tharsis region of Mars. Nature 297, $546-550$.

368 Neukum, G., Jaumann, J., Hoffmann, H., Head, J. W., Basilevsky, A. T., Ivanov, B. A.,

369 Werner, S. C., van Gasselt, S., Murray, J. B., McCord, T., and the HRSC Co370 Investigator Team, 2004. Recent and episodic volcanic and glacial activity on Mars 371 revealed by the High Resolution Stereo Camera. Nature 432, $971-979$.

372 Okubo, C. H., Martel, S. J., 1998. Pit crater formation on Kilauea volcano, Hawaii. J. $373 \quad$ Volcanol. Geotherm. Res. 86, $1-18$.

374 Parfitt, E. A., Head, J. W. (1993). Buffered and unbuffered dike emplacement on Earth 375 and Venus: Implications for magma reservoir size, depth, and rate of magma 376 replenishment. Earth, Moon, Planets, 61 (3) $249-281$.

377 Parfitt, E. A., Wilson, L., Head, J. W. (1993). Basaltic magma reservoirs: factors 378 controlling their rupture characteristics and evolution. J. Volcanol. Geotherm. Res. $379 \quad 55(1-2), 1-14$.

380 Peters, S. I., Christensen, P. R., 2017. Flank vents and graben as indicators of Late 381 Amazonian volcano tectonic activity on Olympus Mons. J. Geophys. Res. 122 (3), 382 $501-523$, doi:10.1002/2016JE005108.

383 Richardson, J. A., Wilson, J. A., Connor, C. B., Bleacher, J. E., Kiyosugi, K., 2017. 384 Recurrence rate and magma effusion rate for the latest volcanism on Arsia Mons, 385 Mars. Earth Planet. Sci. Lttr. 458, 170 -178. 
386

387

388

389

390

391

392

393

394

395

396

397

398

399

400

401

402

403

404

405

406

407

408

Robbins, S. J., Di Achille, G., Hynek, B. M., 2011. The volcanic history of Mars: Highresolution crater-based studies of the calderas of 20 volcanoes. Icarus $211,1179-$ 1203.

Robinson, M. S., Mouginis-Mark, P. J., Zimbelman, J. R., Wu, S. S. C., Ablin, K. K., Howington-Kraus, A. E., 1993. Chronology, eruption duration, and atmospheric contribution of the Martian volcano Apollinaris Patera. Icarus 104, 301 - 323.

Roy, R. F., Beck, A. E., Touloukian, Y.S., 1981. Thermophysical properties of rocks. In: Y. S. Touloukian, W. R. Judd and R. F. Roy (Eds), Physical Properties of Rocks and Minerals. McGraw-Hill, New York, 409-502.

Rubin, A. M., 1992. Dike-induced faulting and graben subsidence in volcanic rift zones. J. Geophys. Res. 97, 1839-1858.

Rubin, A. M., Pollard D. D., 1987. Origin of blade-like dikes in volcanic rift zones In Volcanism in Hawaii. (R. W. Decker, T. L. Wright, \& P. H. Stauffer, Eds), U.S. Geol. Surv. Prof. Paper 1350, 1449-1470.

Schneeberger, D. M., Pieri, D. C., 1991. Geomorphology and stratigraphy of Alba Patera, Mars. J. Geophys. Res. 96 (B2), $1907-1930$.

Scott, E. D., Wilson, L., Head, J. W., 2002. Emplacement of giant radial dikes in the northern Tharsis region of Mars. J. Geophys. Res. 107 (E4), p. 3-1 to 3-10, doi: 10.1029/2000JE001431.

Sigurdsson, H., Sparks, S. R. J., 1978. Lateral magma flow within rifted Icelandic crust. Nature 274, $126-130$.

Simkin, T., K., Howard, A., 1970. Caldera collapse in the Galapagos Islands, 1968. Science 169 (3944), $429-437$. 
409 Smith, D. E. and 23 others, 2001. Mars Orbiter Laser Altimeter: experiment summary after

410 the first year of global mapping of Mars. J. Geophys. Res. 106, 23,689 - 23,722.

411 Walker, G. P. L., 1988. Three Hawaiian calderas: an origin through loading by shallow

412 intrusion. J. Geophys. Res. 93 (B12), 14,773 - 14,784.

413 Warner, S. C. (2009). The global martian volcanic evolutionary history. Icarus 201, $44-$ $414 \quad 68$.

415 Wilson, L., Head, J.W., 2002. Tharsis-radial graben systems as the surface manifestation 416 of plume-related dike intrusion complexes: Models and implications. J. Geophys. 417 Res. 107 (E8), doi:10.1029/2001JE001593.

418 Wilson, L., Head, J. W., 2004. Evidence for a massive phreatomagmatic eruption in the 419 initial stages of formation of the Mangala Valles outflow channel, Mars. Geophys. $420 \quad$ Res. Lttrs. 31 (15), doi:10.1029/2004GL020322.

421 Zuber, M. T., Mouginis-Mark, P. J., 1992. Caldera subsidence and the magma chamber 422 depth of the Olympus Mons volcano, Mars. J. Geophys. Res. 97 (E11), 18295 $423 \quad 18307$. 


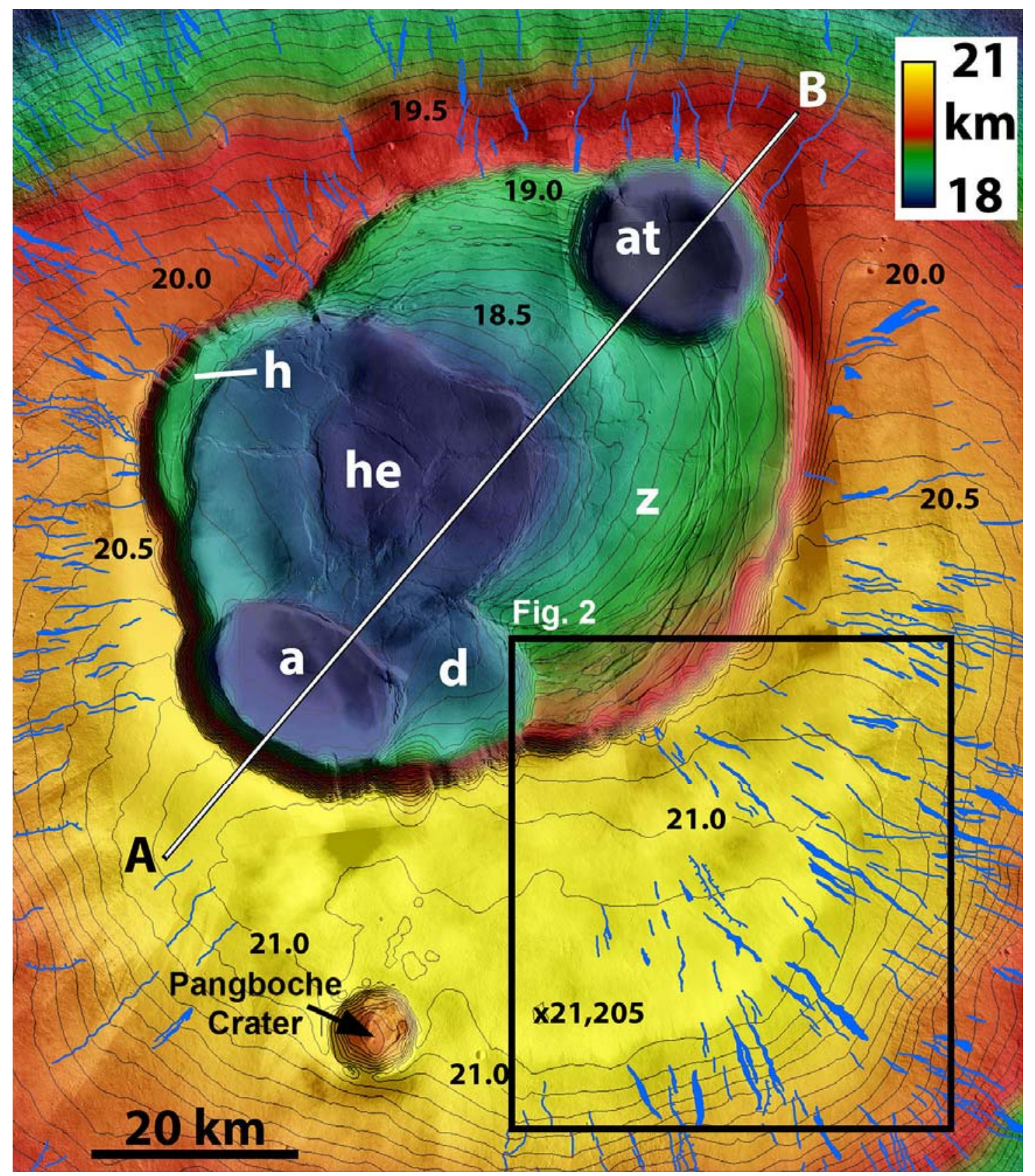

427 Figure 1: Topography of the summit of Olympus Mons. Contour interval is 100 meters, 428 and are labeled in kilometers relative to Mars datum (Smith et al., 2001). Lava channels 429 and lava flow lobes shown by blue lines, and are hachured where only the flow edge can 430 be identified. Note that the highest elevation $(21,205 \mathrm{~m})$ lies to the south of the rim. Box 431 denotes area shown in Fig. 2. Six paterae are identified by lowercase letters ("a" Apollo; 432 "at" - Athena; "d" - Dionysus; "he" - Hermes; "h" - Hera; "z" - Zeus). The location of 433 the profile in Fig. 4 is identified by line A to B. Base image is a mosaic of CTX frames. 


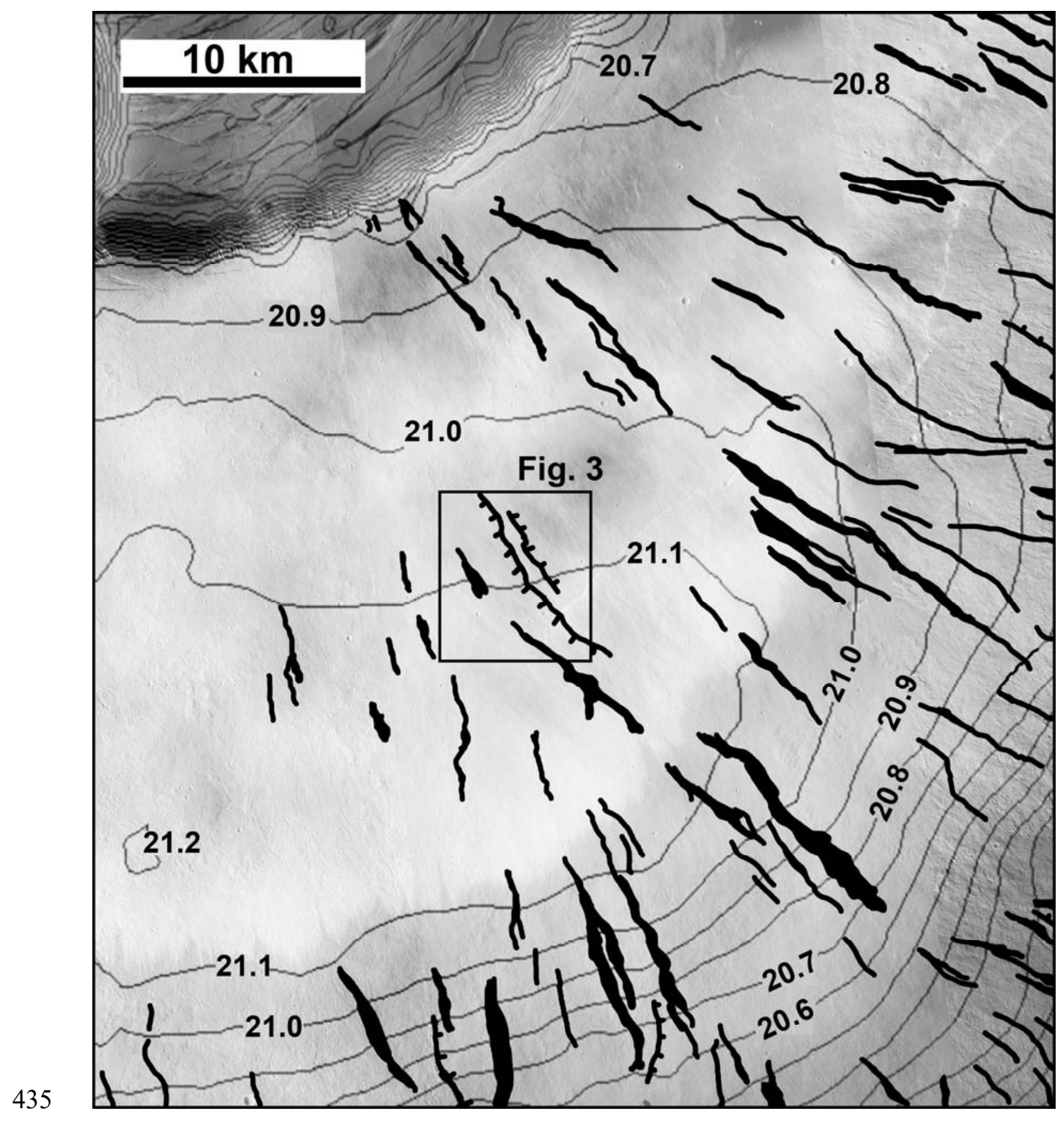

436 Figure 2: Details of lava flows (solid black, except where only the margins can be 437 identified and shown as hachured lines) on SE flank with respect to local topography. Box 438 denotes area shown in Fig. 3. Contour interval is $100 \mathrm{~m}$, and heights are shown in 439 kilometers. See Fig. 1 for location. 


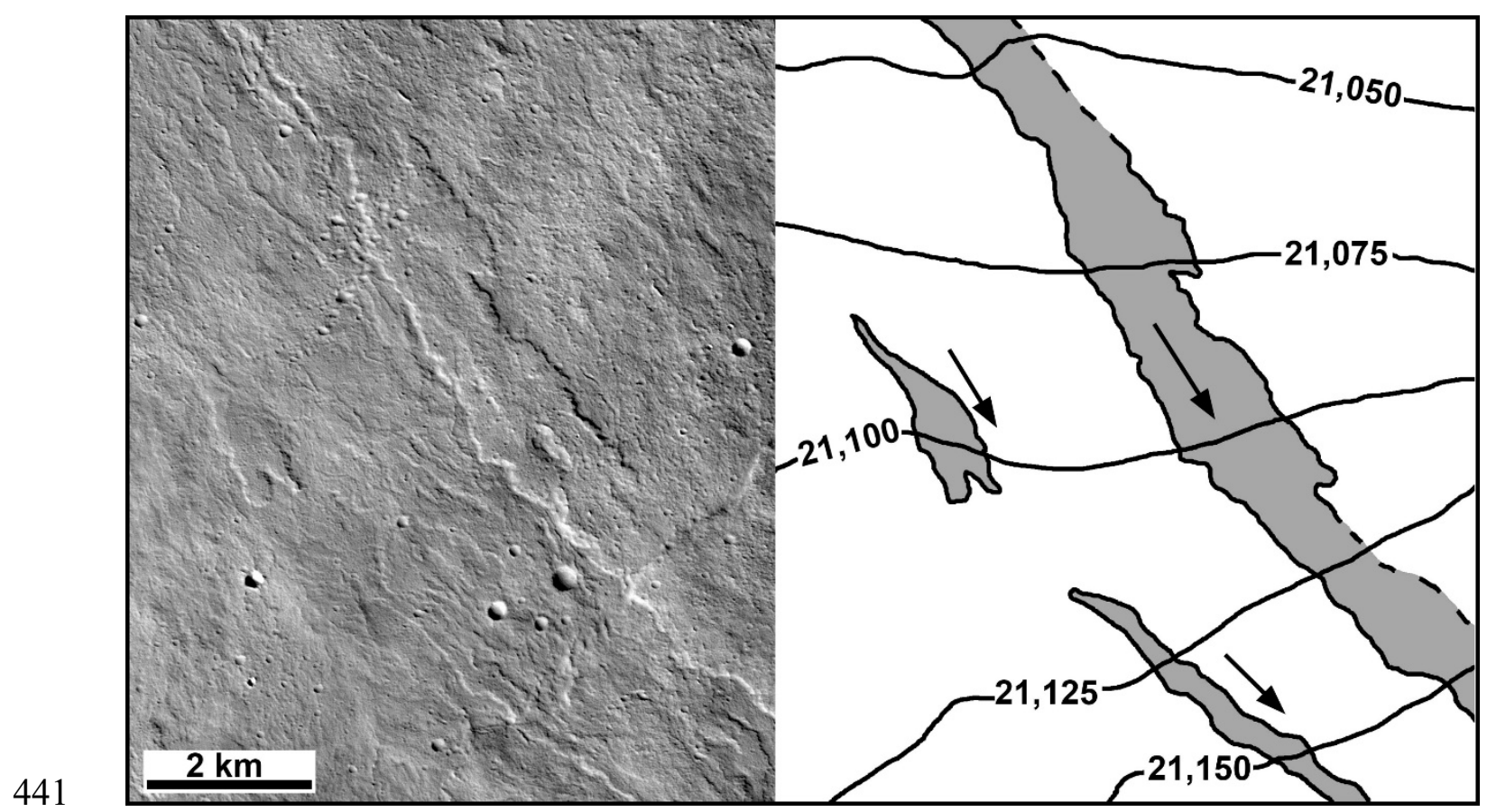

442 Figure 3: Details of flank topography south of the Olympus Mons caldera rim. At left is 443 CTX image B08_012719_1986. At right, is an interpretative sketch of this area. Shaded 444 areas are individual lava flows with dashed line denoting the inferred edge, and arrows 445 denote direction of flow. See Fig. 2 for location. Contour interval is $25 \mathrm{~m}$, and elevations 446 are in meters. 


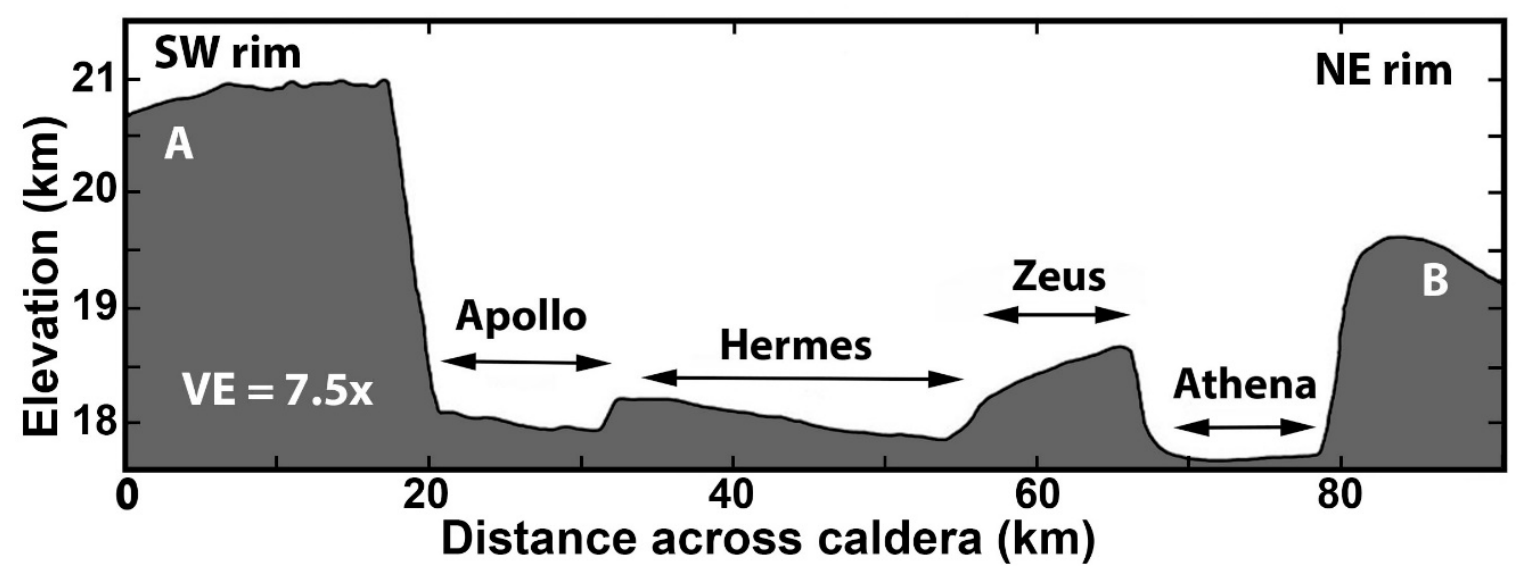

449 Fig. 4: Topographic profile across the floor of Olympus Mons caldera, adapted from 450 Mouginis-Mark (2017). Profile derived from MOLA topographic data. See Fig. 1 for 451 location. The floors of Apollo and Hermes Paterae are tilted upwards towards the highest 452 point on the volcano summit at left of profile. In contrast, Athena Patera is essentially 453 horizontal. The slope of Zeus Patera is interpreted to be due to the central sagging of this 454 patera during an early phase of magma chamber evacuation (Zuber and Mouginis-Mark, 455 1992). 


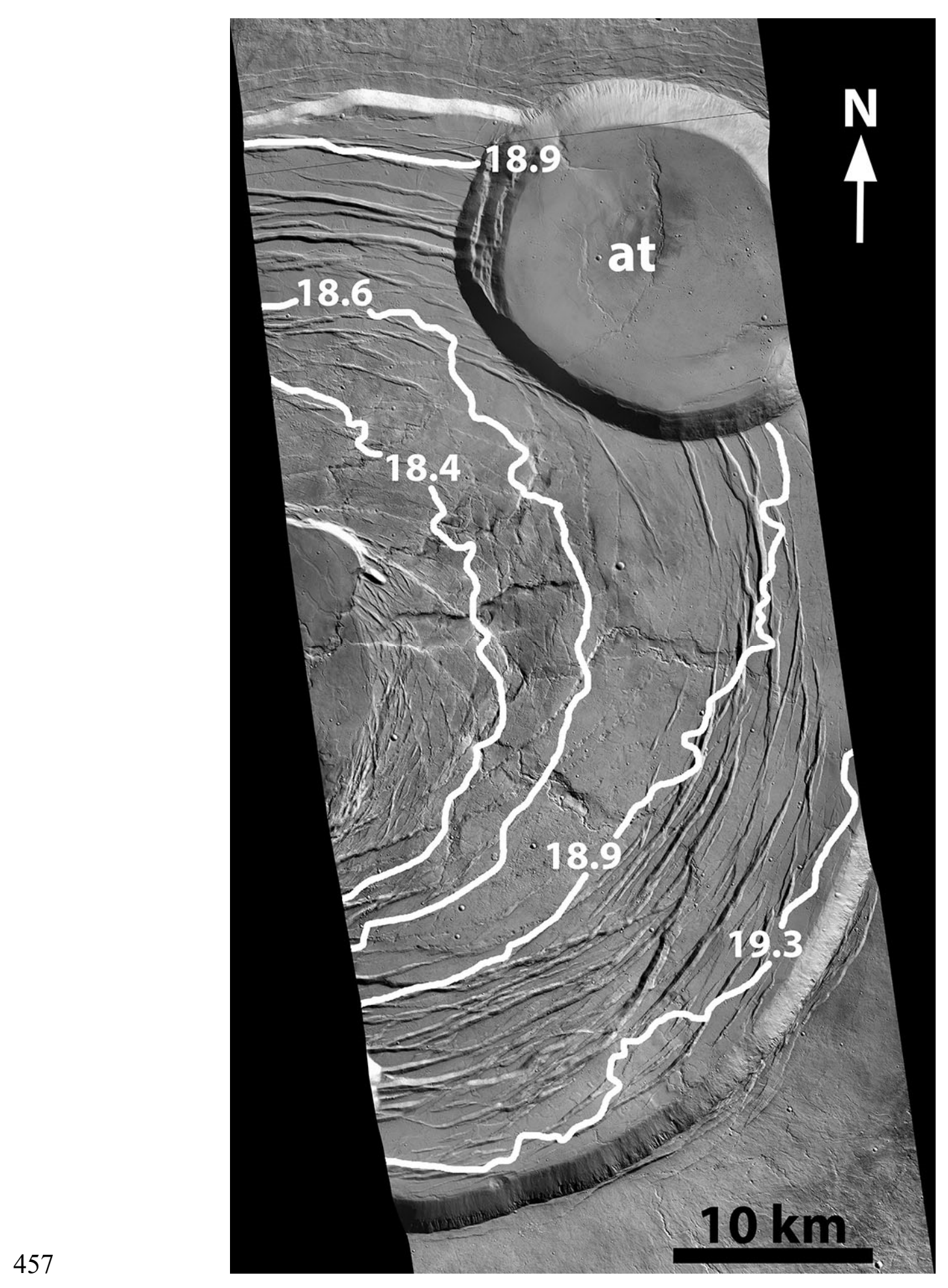

458 Figure 5: Topography of the floor of Zeus Patera within the summit caldera. Four contours $459(18.4 \mathrm{~km}, 18.6 \mathrm{~km}, 18.9 \mathrm{~km}$ and $19.3 \mathrm{~km})$ are illustrated, showing that the SE portion of 460 the floor of Zeus Patera lies at a much higher elevation than the NW floor of the same part 461 of the caldera. "at" is Athena Patera. Base image is CTX frame B08_012864_1986. 


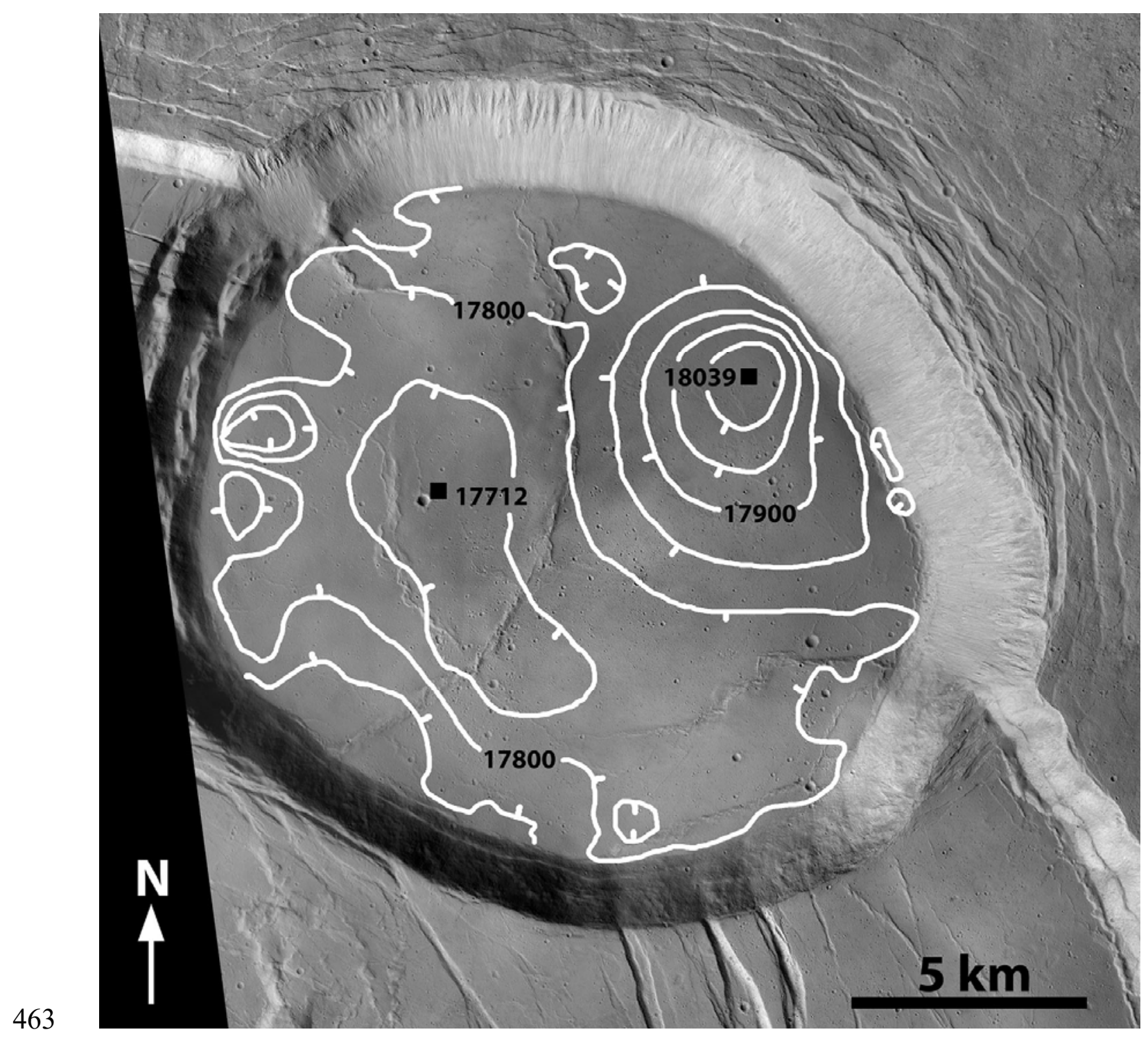

464 Figure 6: Topography of the floor of Athena Patera, illustrating that there is no clear tilting 465 of the floor, although there is a $\sim 100 \mathrm{~m}$ high dome on the NE part of the floor. Contour 466 interval is $50 \mathrm{~m}$, with the highest and lowest points (in meters) identified. Tick marks 467 denote the downslope direction of closed contours. CTX image J06_047228_1985. 


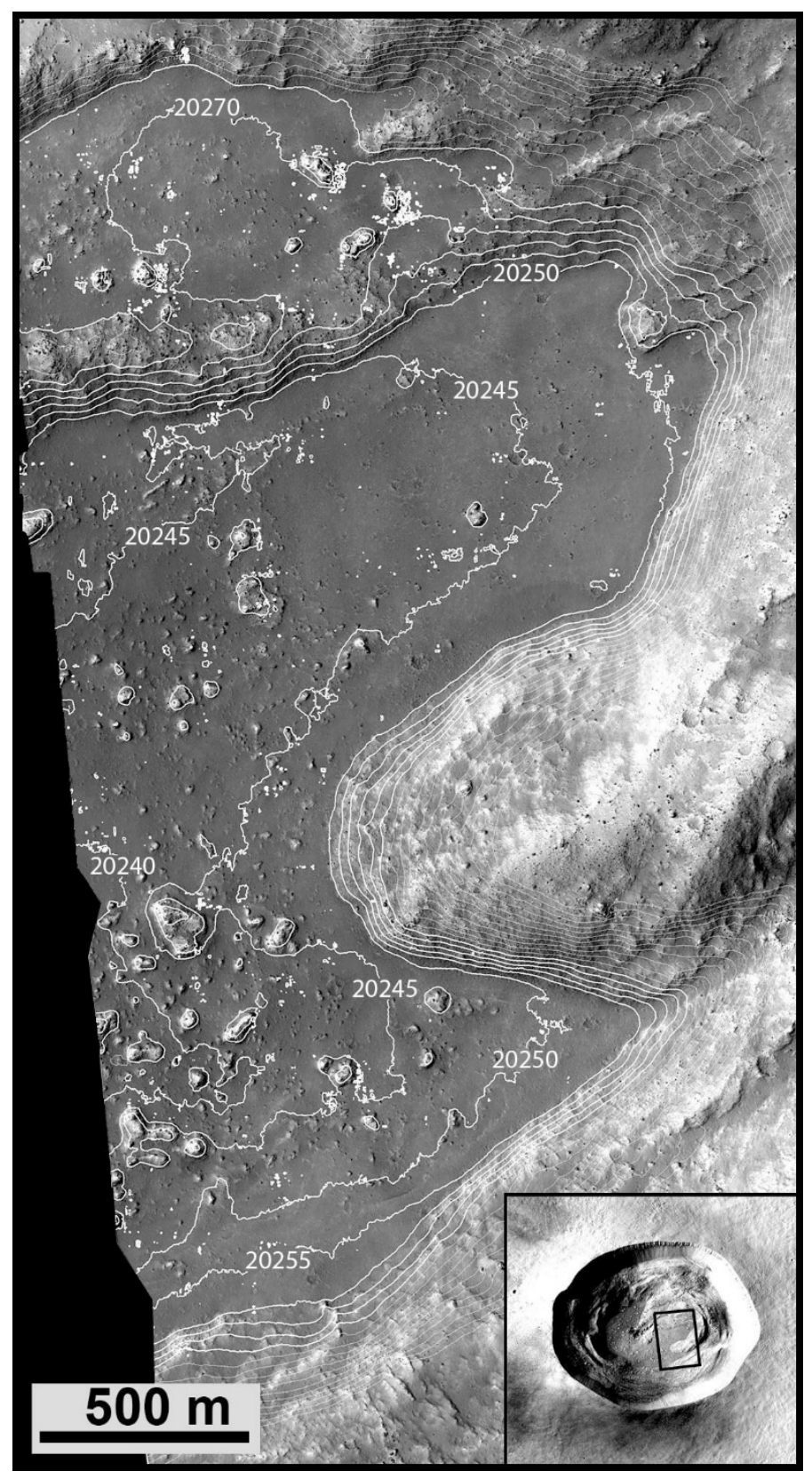

470 Figure 7: Topography of the floor of Pangboche crater, just to the south of the area of 471 maximum uplift at Olympus Mons (see Fig. 1 for location). Contour interval is $5 \mathrm{~m}$, 472 derived by Harold Garbeil from digital elevation model produced from HiRISE images 473 ESP_026024_1975 and ESP_026169_1975. The floor is virtually flat, showing no tilting 474 at all, which implies that either Pangboche formed after the summit inflation ceased or that 475 the crater formed on part of the flank which did not experience inflation. Given the fact 476 that ejecta from Pangboche extends across Apollo Patera (Mouginis-Mark, 2017), the 477 former explanation seems more likely. Insert at lower right shows location on the floor, 478 and is part of CTX image P02_001643_1974. 


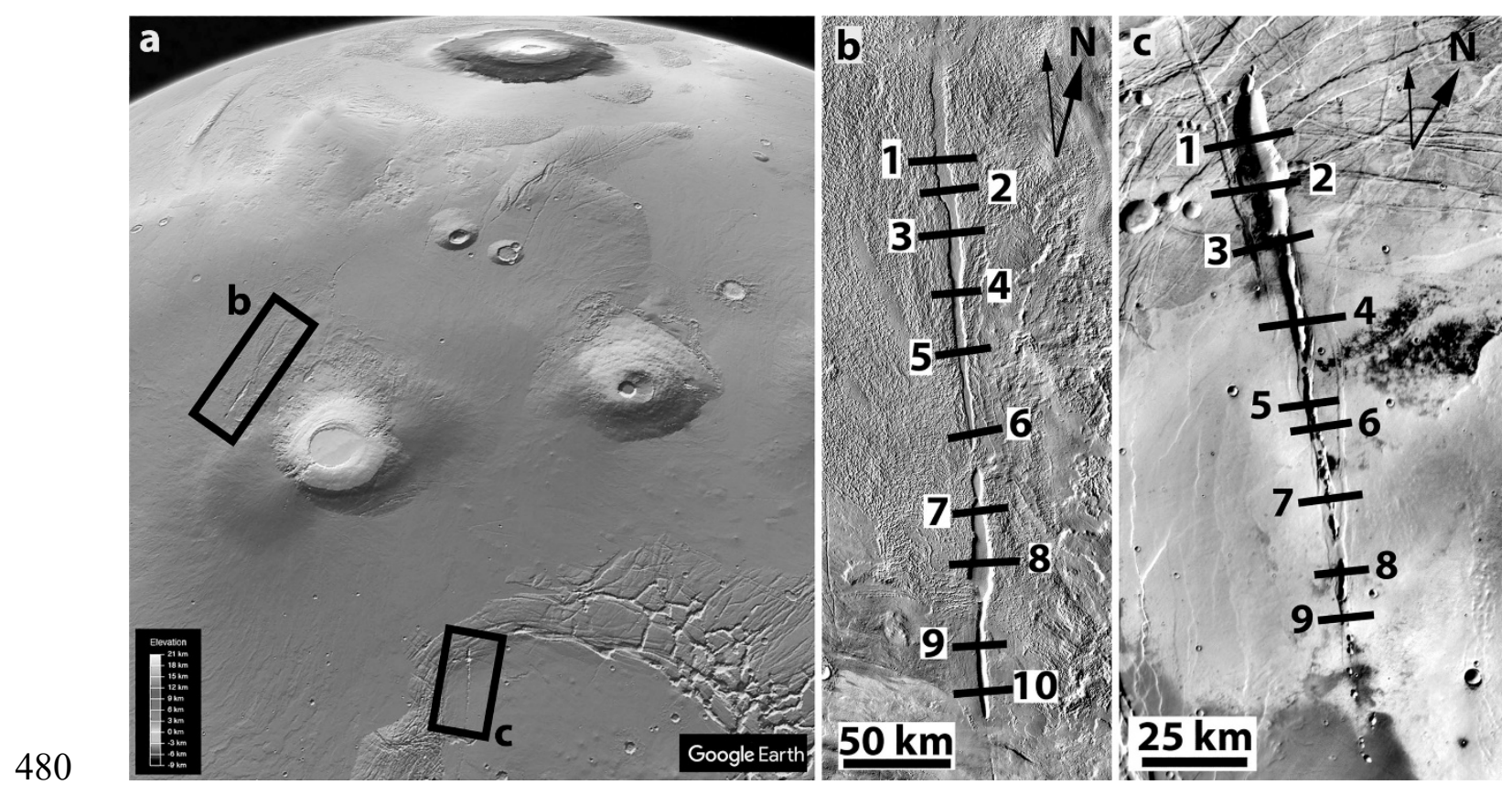

481 Figure 8: Locations of potential radial dikes associated with Olympus Mons. (a) Oblique 482 view, looking northwest, with Olympus Mons at top center. Location of Figs. 8b and 8c 483 indicated. Base image is a grey-scale elevation model derived from MOLA measurements. 484 (b) Aganippe Fossa $\left(7^{\circ} 00^{\prime} \mathrm{S}, 233^{\circ} 40^{\prime} \mathrm{E}\right)$, which outcrops $\sim 1,440 \mathrm{~km}$ to $1,710 \mathrm{~km}$ from the 485 center of Olympus Mons caldera. Profiles included in Table 1 are numbered, small arrow 486 (top right) points to Olympus Mons. CTX image G02_019312_1699. (c) Graben within

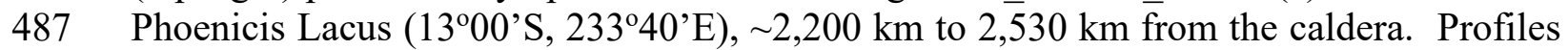
488 included in Table 1 are numbered, small arrow (top right) points along a great circle to 489 Olympus Mons. CTX image B22_018217_1659. 


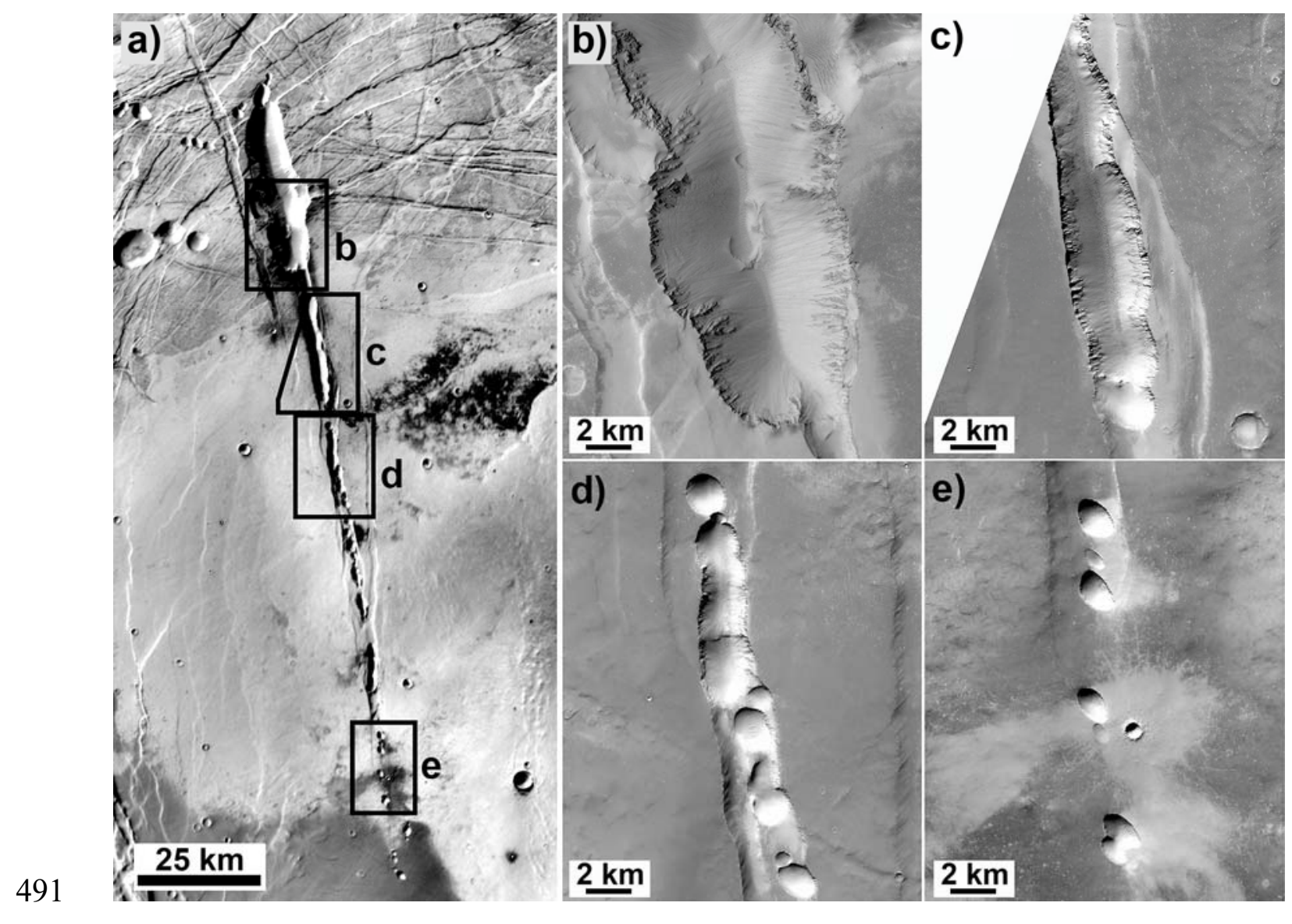

492 Figure 9: Details along Phoenicis graben. Notice that no indications of the top of the dike 493 are visible within the graben or craters along the exposed length of the feature. Images are 494 (a) THEMIS daytime IR mosaic; (b) CTX frame B11_013971_1676; (c) and (d) CTX 495 frame B22_018217_1659; (e) CTX frame P06_003317_1653. 


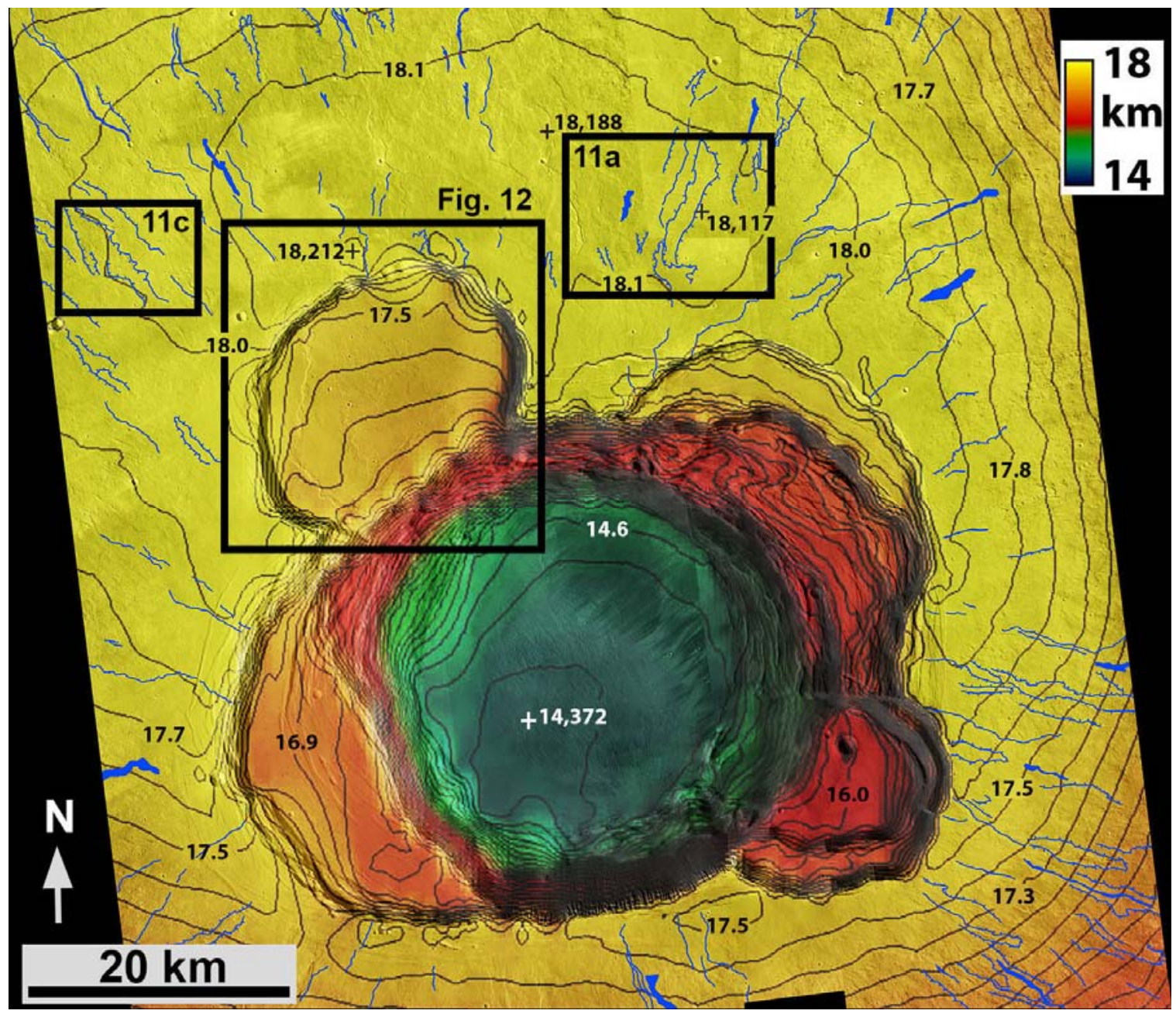

Figure 10: Topography and distribution of mapped lava flows at the summit of Ascraeus Mons. Note that the flows (hachured where only the flow edge can be identified) on the southern rim are perpendicular to the contours and go downhill, indicating no late-stage inflation here. The highest points $(18,212 \mathrm{~m}, 18,188 \mathrm{~m}$ and $18,117 \mathrm{~m})$ are identified on the north rim. Boxes mark the locations of Figs. $11 \mathrm{a}, 11 \mathrm{c}$, and 12 . Contour interval is $100 \mathrm{~m}$, with the lowest point on the caldera floor $(14,372 \mathrm{~m})$ indicated. Base image is a mosaic of 504 CTX frames. 


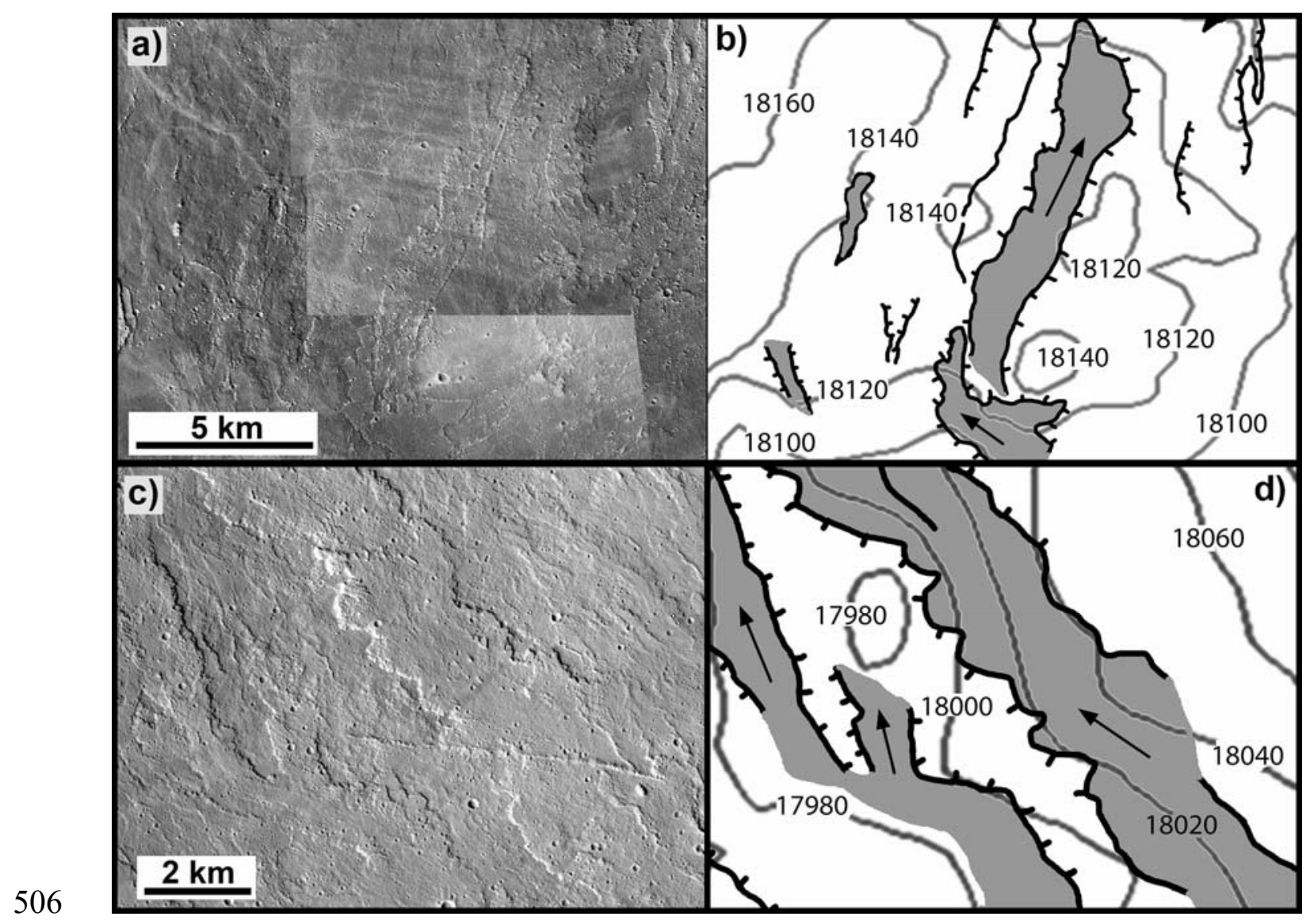

507 Figure 11: Details of two areas ("a" and "c") on the northern flank of Ascraeus Mons, 508 showing disparity between lava flow directions and the local topography ("b" and "d"). 509 Arrows in "b" and "d" show direction of flow. Contours in meters. See Fig. 10 for 510 locations. Flows margins are hachured where the flow edge can be identified. a) is CTX 511 frame P09_004398_1913; c) is CTX frame B06_012006_1912. 


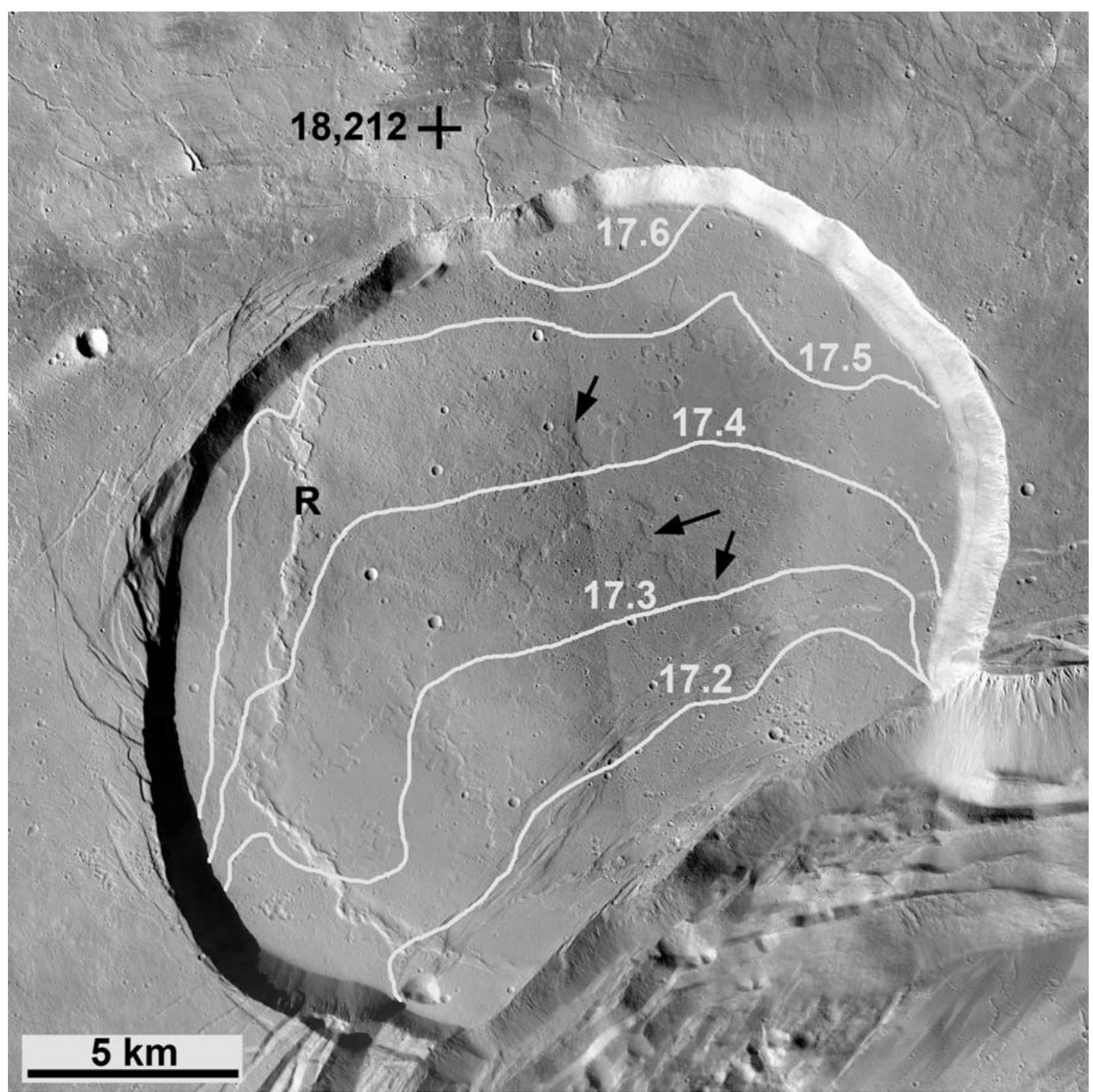

514 Figure 12: Details of the topography of the floor of the NW patera at the summit of 515 Ascraeus Mons, which is presumed to have formed as a flat surface, only to be 516 subsequently tilted towards the south by more than $500 \mathrm{~m}$. Note that the slope of the patera 517 is radial to the highest elevation on the volcano $(18,212 \mathrm{~m})$. Contours from MOLA data 518 are in kilometers, see Fig. 10 for location. "R" identifies a wrinkle ridge which most likely 519 formed by the deformation of the patera floor. Black arrows point to lava flow lobes which 520 appear to travel up-slope. Mosaic of CTX frames B06_012006_1912 and 521 B07_012362_1912. 


\section{Table 1}

523 Estimated volumes of the individual patera within the Olympus Mons caldera. These

524 volumes assume that each collapse event formed an elliptical or circular depression, and

525 that the elevation of the rim of each patera relative to the elevation of the foot of the wall

526 has not been influenced by the inflation of the summit. In part, Apollo, Athena and

527 Dionysus paterea overlap older collapse events, and so two values for the volume change

528 are given.

529

530 Patera Area $\left(\mathrm{km}^{2}\right) \quad$ Ht. $\operatorname{drop}(\mathrm{km}) \quad$ Vol. $\left(\mathrm{km}^{3}\right) \quad$ Total volume $\left(\mathrm{km}^{3}\right)$

531 Apollo 125

3.0

375

532 Apollo

125

0.3

37

412

533 Athena 125

$1.8 \quad 225$

534 Athena 200

1.0

200

425

535 Dionysus 15

$0.8 \quad 126$

536 Dionysus 157

$2.5 \quad 392$

518

537 Hera 330

1.4

462

462

538 Hermes 1250

0.6

750

750

539 Zeus

2827

1.3

3,675

3,675

540

Total Volume $=6,242 \mathrm{~km}^{3}$

541 


\section{Table 2}

544 Dimensions of the Aganippe Fossa and Phoenicis graben. Values in parentheses are 545 influenced by local collapse and enlargement of the surface depressions and are unreliable 546 indicators of dike geometry. See Fig. 8 for profile locations.

547

548

549

550

551

552

553

554

555

556

557

558

559

560

561

562

563

564

565

566

567

568

569

570

571

572

573

574

575

576

577

(a) Aganippe Fossa

$\begin{array}{ccccc}\text { location } & \begin{array}{c}\text { graben } \\ \text { width/km }\end{array} & \begin{array}{c}\text { graben } \\ \text { depth/m }\end{array} & \begin{array}{c}\text { dike } \\ \text { width/m }\end{array} & \begin{array}{c}\text { dike top } \\ \text { depth/km }\end{array} \\ 1 & 11.5 & 220 & 280 & 3.3 \\ 2 & 12.3 & 340 & 425 & 3.5 \\ 3 & 7.0 & 550 & 690 & 2.0 \\ 4 & 6.2 & 640 & 800 & 1.8 \\ 5 & 5.2 & 290 & 360 & 1.5 \\ 6 & 2.9 & 210 & 265 & 0.8 \\ 7 & (8.4) & (960) & (1200) & (2.4) \\ 8 & (17.6) & (1540) & (1930) & (5.0) \\ 9 & (7.9) & (910) & (1140) & (2.3) \\ 10 & 7.1 & 140 & 180 & 2.0\end{array}$

(b) Phoenicis graben

$\begin{array}{ccccc}\begin{array}{c}\text { graben } \\ \text { location }\end{array} & \begin{array}{c}\text { graben } \\ \text { width/km } \\ (10.2)\end{array} & \begin{array}{c}\text { dike } \\ \text { depth/m } \\ (2240)\end{array} & \begin{array}{c}\text { dike top } \\ \text { width/m }\end{array} & \begin{array}{c}(2800) \\ \text { depth/km }\end{array} \\ 2 & (11.0) & (1890) & (2365) & (3.1) \\ 3 & 3.5 & 545 & 680 & 1.0 \\ 4 & 3.2 & 615 & 770 & 0.9 \\ 5 & 5.9 & 430 & 540 & 1.7 \\ 6 & 4.5 & 250 & 310 & 1.3 \\ 7 & 5.3 & 70 & 85 & 1.5 \\ 8 & 3.4 & 210 & 265 & 1.0 \\ 9 & 3.3 & 115 & 145 & 0.9\end{array}$

